DOI: $10.17516 / 1997-1370-0578$

УДК $37.01+801.8$

\title{
Specific Features of Educational and Pedagogical Discourse in the Context of Anthropological Challenges: Socio-Cultural Approach
}

\author{
Maksim V. Kochetkov ${ }^{\mathrm{a}, \mathrm{b}}$ and Igor' A. Kovallevich ${ }^{\mathrm{b}}$ \\ ${ }^{a}$ Norilsk State Industrial Institute \\ Norilsk, Russian Federation \\ ${ }^{b}$ Siberian Federal University \\ Krasnoyarsk, Russian Federation
}

Received 12.01.2020, received in revised form 07.02.2020, accepted 12.02.2020

\begin{abstract}
The relevance of the research is due to the destructive influence of digitalization of society, globalization processes, technological and social progress on a person in his spiritual and physical integrity. These are, first of all, such technological and sociocultural factors as virtualization of the individual's consciousness, cyborgization, loss of subjectivity in the process of merging with information machine complexes, genetic engineering, cloning, pharmaceutical modifying human influence. It is proved that a broad interpretation of educational and pedagogical discourse is adequate for the modern socio-cultural space, which is becoming more complicated for description, which makes it synonymous with such a basic category for pedagogical science as the pedagogical process. The marked tendency is estimated as negative, as the categorical value of basic concepts for pedagogy is lost, the subject of pedagogical science in the system of human Sciences is blurred. Therefore, a highly specialized definition of specific features of pedagogical discourse is justified. It is concluded that the pedagogical category "zone of immediate development" in its socio-cultural hypostasis contributes to the designation of specific features of educational and pedagogical discourse, focusing on specific pedagogical tasks. For example orientation to the zone of the nearest development of the individual in the process of his constant development and self-development assumes permanent diagnostic correction on the part of the teacher in relation to the student. This favors the consistency of the socio-cultural experience transmitted by the teacher with the life experience of the student, the emotional "inclusion" of the latter in the educational process.
\end{abstract}

Keywords: discourse, pedagogical discourse, zone of immediate development, content of education, linguistics, pedagogical system, pedagogical process, communicative competence, competence approach, science studies.

Research area: pedagogy.

(C) Siberian Federal University. All rights reserved

* Corresponding author E-mail address: m-kochetkov@yandex.ru 
Citation: Kochetkov, M.V., Kovalevich, I.A. (2020). Specific features of educational and pedagogical discourse in the context of anthropological challenges: socio-cultural approach. J. Sib. Fed. Univ. Humanit. Soc. Sci., 13(2), 268-277. DOI: 10.17516/1997-1370-0578.

\section{Introduction to the research problem}

The analysis of sociocultural reality in all spheres of human activity is becoming more and more complicated, and therefore the spread of the discursive approach is expanding, when social reality is modeled as a global discourse, namely through the prism of a complex of various discursive manifestations: political, historical, religious, professional, educational, pedagogical, marketing, media, virtual, managerial, mental, national, cultural, gender, and others. In this regard, L.N. Sinelnikova introduces the image of the "matrix of discourse", associating the matrix with the periodic table of D. Mendeleev, which is filled with new elements as they are opened (Sinel'nikova, 2011: 31).

Modeling of sociocultural reality on the basis of various discursive practices is carried out in the Humanities, taking into account such properties of the modern sociocultural space as a global discourse, as "the simulative nature, polyphony, polymorphism, intertextuality, the ability to polylogue, the mixing of often contradictory styles and forms (speech, and not only), orientation to the image, resonances in the form of manipulations, the presence of a target audience" (Pilyugina, 2013: 42).

Regarding education, it "discursivity" (description in the context of a widening spectrum of discursive practices) is quite natural, since the formation of characteristic functions of transmission of culture, preparing the younger generation for life in society, given the diversity of socio-cultural reality. The complexity of the socio-cultural space, especially its active digitalization and virtualization, leads to an increasing fragmentation of the individual's thinking, the prevalence of indirect perception of the surrounding world, namely, information created by other people about it. A person is surrounded by a chaotic cluster of information "clouds" - other people's perceptions and ideas that combine sometimes the most contradictory and incompatible discourses, falls into "communication traps" (Delyagin, 2003: 35).
Civilization is on the threshold of an active, primarily informational, cyborgization of man. In the conditions of fierce competition between cultures, national interests and globalization processes, which are largely related to the interests of transnational entities, the freedom of the future human being is increasingly narrowing its potential horizons. We agree that the processes of cyborgization ${ }^{1}$ in the longterm perspective have the potential to "annul humanity itself and its problems" (Il'in, 2018), and in the medium-term-create for representatives of the elite not only enormous advantages in professional competence, but also unlimited possibilities of control over "service" people (Il'in, 2018).

Anthropological discourse, therefore, will play an increasingly pronounced integrating role as the cyborgization of man in connection with the growing threat of technological and social progress to man in his bodily and spiritual integrity.

The above makes it particularly relevant to identify the specific features of educational and pedagogical discourse, with its essential anthropo-forming and anthropo-preserving functions, since pedagogical knowledge is focused primarily on the translation of the best examples of the culture of the past, including the distinctive cultural features of Homo sapiens. The designated function of pedagogical knowledge in combination with its advanced purpose is designed to adapt the individual to the technological and anthropological challenges of time, affecting the very spiritual and bodily nature of man.

\section{Theoretical basis of the study}

The Council of Europe identifies five groups of relevant core competencies, one of which is discursive competence. Its essence is to achieve the goal, knowledge and possession

\footnotetext{
1 In the future, when we talk about cyborgization, we will also mean cloning, genetic modification, pharmaceutical transformation, the influence of GMO nutrition, etc.
} 
of various methods of obtaining information not only in writing, but also in oral communication. In the Russian science of discursive competence, communicative competence is very close, in terms of its content and significance. So, taking into account many modern requirements to the specialist (system thinking, work with artificial intelligence, skills of intersectoral communication, multilingualism and multiculturalism, creativity, ability to artistic creativity, aesthetics, ability to manage projects and processes, work in groups, etc.), the communicative competence of the teacher is considered by I. I. Barakhovich as a metacompetence in the supra-professional and professional aspects (Barahovich, 2015: 7-8). At the same time, the essence of pedagogical activity is seen in its communicative nature (Barahovich, 2015: 11), which is difficult to disagree with.

At the same time, in domestic science in recent years there has been an active study of the actual discursive competence (competence).

Linguists and linguists, of course, associate the concept of discourse primarily with the text. Discourse refers to "a specific communicative event, recorded in written texts and oral speech, carried out in a certain cognitive and typologically determined communicative space" (CHernyavskaya, 2009: 143). Discourse denotes a communicative and mental process that leads to the formation of a certain formal structure-the text (CHernyavskaya, 2009: 144).

Discourse is also understood as "a set of thematically related texts: the texts that are combined into a discourse are addressed in one way or another, to one common theme. The theme of discourse is revealed not in one separate text, but intertextually, in the collective interaction of many separate texts" (CHernyavskaya, 2009: 144).

However, linguists and linguists have a concept of metalinguistic discourse. This type of discourse includes "the exchange of linguistic ideas, which is carried out both in space (synchronously) and in time (diachronously), both within the same scientific paradigm, and interparadigmally" (Ivanova, 2015: 107).

Discourse is defined in modern linguistic theory (Yu.N. Karaulov, O.I. Kucherenko,
T.A. van Dejk, etc.) as a complex communicative phenomenon that, along with the linguistic characteristics inherent in the text, has extralinguistic parameters (participants of communication, their communicative goals, intentions, pragmatic attitudes, social roles, background knowledge about the conditions of communication: about the interlocutor, time, space) (Suvorova, 2012: 85). The text is not only the basis of communication, but also a means of achieving the communicative goals of its participants. Discourse in this regard is not only the product and initial basis of speech activity, but also the process of its creation, which is determined by extralinguistic factors, that is, the communicative context and conditions of communication (Eluhina, 2002).

Thus, modern linguistic and linguistic achievements fit perfectly into the trend of an increasingly broad understanding of discourse: in the prism of postmodern ideas, discourse is "a transcendent phenomenon; a special form and way of social being, infinitely changing, fragmenting, mixing the real and the unreal" (Ivanova, 2015). As it follows from the position of a number of Russian language scientists, the discursive approach goes far beyond the selection of texts, justification of the relevant selection criteria.

\section{Specific features \\ of pedagogical discourse}

What is the specificity of such a direction of "discursification" of humanitarian knowledge as pedagogical discourse? Is it relevant to define such specifics? Or is it insignificant in comparison with the understanding of discourse in the same linguistics?

In the most General approximation, the relevance of pedagogical knowledge is due to the answer to the questions - "what to teach?" ("What to learn?") and "how to teach?" ("What methods of self-change are most effective?").

The procedural specificity of pedagogical discourse is evaluated by scientists quite variously, although the very processality is not questioned. S.L. Suvorova in connection with the study of pedagogically adapted texts of culture resorts to the concept of spreading, focusing on polyphony, value-semantic satura- 
tion of communication, multi-level elements of the marked process (Suvorova, 2012: 85). N.V. Elokhina draws attention to the extralinguistic factors in the process of creating a discourse (Eluhina, 2002). E. Kozhemyakin (Kozhemyakin, 2010: 27) notes that educational and pedagogical discourse is "regulated by certain historical and socio-cultural codes (traditions) meaning-forming and meaning-reproducing activities aimed at the translation, reproduction and regulation of certain values, knowledge, skills and behaviors" (Kozhemyakin, 2010: 27).

A broad and process-oriented interpretation of pedagogical discourse, in our opinion, puts the concept of pedagogical discourse on a par with such a fundamental and subject-forming category for pedagogical science as the pedagogical process, taking into account the dynamic aspect of interpretations of discourse. We see the absolute synonymy of the categories "pedagogical process" and "pedagogical discourse", if we agree, for example, with the position of S.L. Suvorov regarding pedagogical discourse: "objectively existing dynamic system of value-semantic communication of subjects of the educational process, functioning in the educational environment of the University, including participants of the discourse, pedagogical goals, values and content component, providing students with advanced experience in the design and evaluation of any pedagogical or social phenomenon in accordance with the norms of cultural activity" (Suvorova, 2012: 85).

Let us emphasize that the opinion of the scientist fully reflects the trends of "discursification" of humanitarian knowledge, at least its linguistic direction. The consequences of following pedagogical science in the Wake of the "discursification" of humanitarian knowledge, that is, the attitude to discourse as a megacategory, sometimes leads to ambiguous circumstances in terms of assessing positivity or negativity. Let's imagine three of them.

The first circumstance, unlike the others, is, in our opinion, indisputably positive. It consists in the formation of pedagogical knowledge as integrating among the Humanities as they "discursification": the concept of discourse is directly related to all the key pedagogical fea- tures of human development and self-development-setting goals, determining the content and methods of change or self-change of the individual in accordance with the goals relevant to the person or social group. This is particularly relevant, given the previously identified anthropological challenges determined by the processes of cyborgization.

Note that in pedagogical anthropology is quite common understanding of the distinctive essence of human existence as the ability to educate and self-education (B.M. Bim-Bad, O. Bol'nov, H.-G. Gadamer, V. Dil'tej, K.D. Ushinskij, M. Hajdegger, M. SHeler, etc.); qualitative features of education and self-education of a person determine the main difference between a person and an animal. Education in this case is a fundamental way of being a person (Kochetkov, 2017). Therefore, education, as well as other categories that reflect its content, including the concept of discourse, is rightly considered as integrating in humanitarian knowledge - that is, knowledge about man (the word "humanitarian" is etymologically derived from the Latin "humanus", i.e. "human").

The second circumstance is determined by the fact that in terms of science, pedagogical discourse is rightly seen as the basis of not only humanitarian, but also any scientific knowledge: its communicative aspect is characterized by the "setting of the initiating party to preserve or change the scientific views of the recipient, models of his scientific experience" (Krotkov, 2010: 4). This implies not so much face-to-face as correspondence communication: "in science, the author's cognitive discourse is built on the background and with the participation of other researchers discourses" (Krotkov, 2010: 18). At the same time, other discourses are taken into account by the author to the extent that "their content can be projected on the research methodology and the cognitive image of the object of knowledge that he builds. According to the goals (intentions), the communicative aspect of scientific discourse should be divided into representative, when the author of his message has the intention to form or change the named image in the recipient; apprezitivny, when the recipient is suggested through the text that such and such a research 
situation, hypothesis or theory is preferable to such and such; prescriptive, when verbal means intend to change the behavior of the recipient in a certain research situation, to organize this behavior" (Krotkov, 2010: 18).

Here we will note that the communicative aspect of the description of scientific knowledge is most often focused on the high professional level of the recipient, at least commensurate with the level of the author of scientific views. In the field of education, the teacher is called upon to adapt the gap between the scientific level of discourse and the level of readiness for its perception by students. Modern school and University, in our opinion, are generally far from solving this pedagogical problem at a level that would contribute to the development of creative qualities of the individual, becoming a professional researcher. There is a practice of pedagogical communication in school and higher education, based not on a "live" scientific discourse, where the designated intentions and manifestations of communication of scientific discourse unfold in time, but dead, petrified content in the form of a winning" point of view, namely postulated object-subject features of a certain area of knowledge, relevant principles, methodological bases, established laws, etc. This is fundamentally contrary to the laws of effective development of a creative person. The justification of the presented thesis will be developed later.

The third circumstance is connected with the fact that the attitude to pedagogical discourse as a metacategory contributes to the consideration, reinterpretation through the prism of pedagogical discourse of literally all pedagogical knowledge. The practice of such reinterpretation as a result of hypertrophied dominance of certain pedagogical categories (for example, "competence", "competence", "pedagogical innovation", etc.) often leads to the fact that there is no discovery of fundamentally new laws of educational activities (Vygotskij, 1991), the impression of deja vu is created. And if there is nothing bad for the philosophy of education in deja vu due to the always useful understanding of new facets of the studied phenomena, then with regard to the practice of education, the detailed identification of specific, practice-oriented features of pedagogical categories is relevant. After all, the extended interpretation of pedagogical categories and corresponding "innovative" concepts by authoritative scientists is often accompanied by their broad imposition on educational practices. And this, in turn, gives significant trouble to teachers, educators and teachers, other teaching staff of educational institutions due to the bureaucratic side of educational activities (large amounts of processing of work programs, curricula, educational literature, transformable forms of education and education, criteria for evaluating the effectiveness of educational activities).

\section{Pedagogical discourse \\ and perspective methodological approaches bases of development of educational theory and practice}

The category of discourse (including pedagogical discourse, discursive competence, and competence) is becoming increasingly popular. Perhaps the most "discursively rich" today is the scientific understanding of the political sphere of interdisciplinary theory and practice. It seems that education in the future will not yield to the political sphere in terms of describing the discursive practices that define it. The common thing that unites most studies of political discourse is that "they are conducted, as a rule, within the boundaries of Philology and linguistics, not political science; and even integrative studies acquire semiotic shades" (Pilyugina, 2013: 44). In other words, the text, the sign system acts as the integrating core of this discursive practice.

Given the above, we tend to focus on the fact that, despite the increasing attention in various Sciences to the procedural side of discourse, the textual context as an integrating core of this concept should not be blurred.

It seems that for the consideration of pedagogical discourse it is fundamentally important that the semiotic basis of discourse, its textual hypostasis constitute the key integrant of the concept of "pedagogical discourse". Therefore, the problems of education in the form of questions "what to teach?" and "how to teach?" in 
the case of pedagogical discourse, it is necessary to interpret first of all in the context of the content of education ("what to teach?"): content education must "fall" and flow from the discursive sphere of potential distribution of individual accumulated human socio-cultural experience. "How to teach?" in this case, it is subordinate "what to teach?", taking into account the conditionality of the dominance of cognitive processes over communicative ones, since they are interconnected and inseparable.

Turning to the question "how to teach?" in its hierarchical subordination to the question "what to teach?" subject areas of knowledge should be of interest primarily in the aspect of individually oriented scientific-heuristic process of obtaining relevant knowledge. Answer the question "how to teach?" relevant based on: the content context of the student's life interests, his Outlook; significant household and professional needs; age-related curiosity and individual abilities; existing and constantly developing in the process of educational activity needs for new knowledge; permanently formed experience of scientific knowledge; interested cognitive response to certain aspects of the heuristic process of the emergence of the studied area of knowledge. The heuristic process of the emergence of the studied area of knowledge, in turn, is hidden (often not recognized by the layman) in the communicative discourse of the description of scientific knowledge: the explicit or implicit collision and cooperation of various heuristic ideas, the dialogue of points of view, the search for necessary and sufficient research methods.

The current practice of education, alas, comes from the logic of describing various Sciences in their object-object vestments, in their system-forming structure of principles and methodological foundations. The widespread practice of education is determined by the fact that the foundations of science are distributed by the individual in the form of an alternative, established system of views, knowledge is not "rediscovered", not self-actualized at a potentially possible level. Principles, postulates, and other generalizing and established scientific positions should crown the study of both individual blocks of the discipline and its entire integrity, and not constitute the appropriate initial stages.

With today's practice of designing the content of education, which reflects the centuries-old traditions of mass education, the most diligent future specialists "gnaw the granite of science", partially checking the learned in quasi-professional and professional activities. However, the weak expression of the student's "rediscovery" of knowledge, as well as the acute need for it, greatly complicate the ability of a person to "go" beyond the established theoretical postulates in the future, to make socially significant discoveries. Thus, in schools and universities there is a practice of teaching, based primarily on the logic of describing scientific knowledge, and not on the mechanisms of obtaining it in the context of the life needs of the individual. The corresponding education system significantly limits the development of the student's creative potential.

Indirect confirmation of this - a significant number of recognized scientists, artists, whose professional development for one reason or another significantly went beyond the framework of the system of education adopted at the time, whose diploma of education did not correspond to the profile of the field of knowledge that brought them fame: R. Bojl', I. Bunin, K. Gauss, G. Grasman, D. Dal'ton, G. Devi, G. Kirhgof, I. Kepler, N. Kopernik, L. Landau, P. Lebedev, G. Lejbnic, M. Lomonosov, Sh. Ramanudzhan, A. Solzhenicyn, Zh. Fabr, M. Faradej, P. Ferma, R. Fisher, E. Habbl, A. Holl, K. Ciolkovskij, M. SHolohov, U. Eshbi, L. Ejler. The list of names presented is only a small fraction of those recognized creators whose biography absolutely confirms the thesis we have outlined in all its aspects. In fact, a detailed examination of the biographies of all the established talents, in our opinion, would not leave room for exceptions in respect of their "drop-out" from the education system.

The theoretical grounds for changing the situation in the education system are connected, in our opinion, with such a category "pedagogical discourse", the definition of which implies an updated hierarchy of its integrating bases: in accordance with the dominant role of the key methodological question "What to 
teach" and the subordinate role of the methodological question "how to teach". Technological support of the presented hierarchy can be productive, in our opinion, as a result of the use of such a construct as the "zone of the nearest development" of a person, namely its cultural and ideological aspect.

In 1920-1930 years S.L. Rubinstein and A.N. Leontiev, based on the cultural-historical theory of L.S. Vygotsky, created the theory of activity. At the same time, one of the key concepts of L.S. Vygotsky's cultural-historical theory is the concept of the zone of immediate development. It is a theoretical construct for characterizing the relationship between learning and human mental development.

In cultural-historical theory of L.S. Vygotsky zone of proximal development defines a "function, not ripe yet but are in the process of maturing, that will Mature tomorrow, that are currently still in its infancy; the functions that can be called not the fruit of development, kidney development, colors development, that is, the fact that only Matures" (Kochetkov, 2017: 391-410).

The zone of immediate development is determined by the content of those tasks that the student can not yet solve on their own, but is able to solve in a joint activity with the teacher. In the cultural and world Outlook aspect, the zone of immediate development is the developed and "potentially close" Outlook of the student. What "falls" into the sphere of his erudition and actual needs of knowledge, everyday needs and interests, life experience and aspirations, can become under the guidance of the teacher his own property (skills, abilities, personal qualities). This, in our opinion, is the pedagogical discourse underlying the answer to the question "what to teach?" and important for the answer to the question "how to teach?"

From the point of view of cultural and historical theory, properly organized training is based on the student's zone of immediate development, namely, on the Outlook, everyday experience and needs, on those mental processes that begin to develop in his co-creation with the teacher, and then function in his independent activity. The concept of "zone of immedi- ate development" allows us to characterize the possibilities and prospects of human change, contributes to the diagnosis of professional knowledge and personal and ideological qualities, for example, using a socioparemiological approach (Kochetkov, 2018).

On the basis of the cultural-historical theory of L.S. Vygotsky, the theory of activity of S.L. Rubinstein and A.N. Leontiev in the second half of the last century, P.Ya. Galperin developed a theory of systematic and gradual formation of mental actions. He proceeded from the fact that it is necessary to teach not in order to give the sum of knowledge, but in order to teach to act.

Over the past fifteen years, the reformation of the Russian higher school has been carried out with a focus on such a super-category as competence (competence). The competence-based approach in its practice-oriented orientation does not contradict the practice-oriented essence of the noted Russian traditions, which are fairly called activity-oriented.

Moreover, some historians of education believe that the Russian activity traditions in education have largely served as the basis for the competence approach. However, in its present form, the competence approach, in our opinion, could be significantly enriched by the national activity theory and practice, primarily in the aspect of the key concept of "zone of immediate development", including the development of the discursive approach in education. In the latter case, the vast number of competencies and competencies that have been substantiated by academic educators over the past fifteen years could be ordered, in some cases combined, as a result of comparison with discursive practices.

According to the definition proposed by the Council of Europe, competence is the sum of knowledge, skills and personal qualities that allow a person to perform various actions. The implementation of learning technologies based on the construct "zone of immediate development" involves a constant diagnosis of human mental development. Therefore, when implementing the competence approach in the context of the category "zone of imme- 
diate development", there are methodological grounds for the coordination of training and the formation of personal qualities. After all, the technologies for developing skills with skills and technologies for forming personal qualities differ significantly, which in the implementation of the competence approach currently causes significant difficulties, making it urgent to search for an integrating basis that unites the mentioned technologies. Such a basis could be the zone of immediate human development in the context of a "fan" of potentially possible discursive practices that "weave" in themselves both personal and professional qualities.

\section{Conclusion}

Thus, the zone of immediate human development in existential (being) terms, in the cultural and ideological aspect is the main pedagogical discourse, which is relevant as a methodological basis for the practice of education, technologies of training and education, design of the content of education. Orientation to the zone of the nearest development of the individual in the process of his constant development and self-development assumes permanent diagnostic correction on the part of the teacher in relation to the student in the process of their communicative interaction. This contributes to the interconnection of the socio-cultural experience transmitted by the teacher with the life experience of the student, the emotional "inclusion" of the latter in the educational process, his interested cognitive activity. In specific conditions of interpersonal communication of participants of educational activity orientation of the teacher on a zone of the nearest development of the student favors individualization of training and education, namely intellectual and emotional support of the separate participant of educational activity, effective use of its creative potential on the basis of individual abilities, life and professional preferences. The pedagogical category "zone of immediate development" in its cultural and ideological aspect contributes to the presentation of pedagogical discourse primarily in the aspect of the problems of designing the content of education, taking into account the conditionality of separate consideration of communicative and cognitive processes.

Another key conclusion of this study is to justify the prospects for improving the competence approach in the context of educational and pedagogical discourse, as well as the theoretical construct "zone of immediate development", the corresponding concepts and technologies of educational activities. Thus, the development of the educational sphere in the direction of the most diverse range of discursive practices creates conditions for ordering and combining a truly vast range of competencies and competencies (the result of active research of pedagogical science over the past fifteen years) in accordance with the designated educational discourses. In our opinion, the main discursive practices that are relevant for the educational and pedagogical sphere of activity are pedagogical, psychological, social, environmental, professional, scientific, existential, managerial, virtual, mental, national-cultural, political, historical, religious, marketing, media, gender, anthropological.

\section{References}

Barahovich, I.I. (2015). Kommunikativnaya kompetentnost' pedagoga: professional'nyj i nadprofessional'nyj aspekt [Teacher's communicative competence: professional and abover-professional aspects]. Krasnoyarsk, $284 \mathrm{p}$.

Chernyavskaya, V.E. (2009). Lingvistika teksta. Polikodovost'. Intertek-stual'nost'. Interdiskursivnost' [Text linguistics. Policebot. Intertextuality. Interdiscursivity]. M., Knizhnyj dom «LIBROKOM», $248 \mathrm{p}$.

Delyagin, M.G. (2003). Mirovoj krizis: obshchaya teoriya globalizacii [World crisis: General theory of globalization]. M., INFRA-M, $768 \mathrm{~h}$.

Eluhina, N.V. (2002). The role of discourse in intercultural communication and the method of formation of discursive competence. In Inostrannye yazyki v shkole, 3, 9-12. 
Il’in, G.L. (2018). «Transhumanization» of modern education. In Vysshee obrazovanie v Rossii, 1 (219), 133-142.

Ivanova, V.I. (2015). Language discourse and linguistic (linguistic and metalinguistic) discourse [Language discourse and linguistic (linguistic and metalinguistic) discourse]. In Trudy Mezhdunarodnoj nauchno-prakticheskoj konferencii «YAzykovoj diskurs v social'noj praktike» [Proc. Int. Scientific and Practical Conf. "Language discourse in social practice”]. Tver', 105108.

Kochetkov, M.V. \& Noskov, M.F. (2019). Flipped classroom technology in engineering education: Criteria of educational innovation. In Science for Education Today, 3 (9), 185-199. DOI: http://dx.doi.org/10.15293/2658-6762.1903.11

Kochetkov, M.V. (2017). Teaching or serving? Reflections in connection with the Federal Law "On Education in the Russian Federation". In Pedagogika, 10, 62-68.

Kochetkov, M.V., Speranskij, A.V. \& Speranskaya, A.N. (2018). Socio-paremiological approach to diagnostic support of educational activity. In Vestnik Omskogo gosudarstvennogo pedagogicheskogo universiteta. Gumanitarnye issledovaniya, 1, 120-124.

Kozhemyakin, E. (2010). Educational and pedagogical discourse. In Sovremennyj diskurs-analiz, 1, 27-46, available at: http://discourseanalysis.org/ada2_1/st17.shtml

Krotkov, E. (2010). Nauchnyj diskurs. In Sovremennyj diskurs-analiz, 1, 4-18, available at: http://discourseanalysis.org/ada2 1/st17.shtm1

Pilyugina, E.V. (2013). Discourse in politics and politics as discourse: actual resonances of postmodern social life. In Vestnik CHelyabinskogo gosudarstvennogo universiteta, 23 (314), 4248.

Sinel'nikova, L.N. (2011). Modern discursive «matrix» as an indicator of the state of public consciousness. In Informacionnyj Vestnik Foruma rusistov Ukrainy, 14, 104-118.

Suvorova, S.L. (2012). Phenomenology of the study of the concepts of "discourse" and "pedagogical discourse". In Vestnik YUUrGU, 4 (263), 84-87.

Vygotskij, L.S. (1991). Pedagogicheskaya psihologiya [Pedagogic psychology]. M., Pedagogika, $480 \mathrm{p}$. 


\title{
Специфические особенности педагогического дискурса в условиях антропологических вызовов: социокультурный подход
}

\author{
М.В. Кочетков а,б, И.А. Ковалевичб \\ ${ }^{a}$ Норильский государственный индустриальный институт \\ Российская Федерачия, Норильск \\ ${ }^{6}$ Сибирский федеральньй университет \\ Российская Федераиия, Красноярск
}

\begin{abstract}
Аннотация. Актуальность исследования обусловлена деструктивным влиянием на человека в его духовной и телесной целостности цифровизации общества, глобализационных процессов, технологического и социального прогресса. Это, прежде всего, такие факторы, как виртуализация сознания индивида, киборгизация, потеря субъектности в процессе слияния с информационными машинными комплексами, генная инженерия, клонирование, фармацевтическое модифицирующее влияние. Обосновано, что современному усложняющемуся для описания социокультурному пространству адекватна широкая трактовка образовательно-педагогического дискурса, что делает его синонимичным такой базовой для педагогической науки категории, как педагогический процесс. Отмеченная тенденция оценивается как негативная, так как уходит категориальная ценность базовых для педагогики понятий, размывается предмет педагогической науки в системе наук о человеке. Поэтому предложено узкоспециализированное определение специфических особенностей педагогического дискурса. Сделан вывод о том, что педагогическая категория «зона ближайшего развития» в ее социокультурной ипостаси способствует обозначению таких особенностей, акцентированию внимания на специфических педагогических задачах. Например, ориентация на зону ближайшего развития индивида в процессе его постоянного развития и саморазвития предполагает перманентную диагностическую коррекцию со стороны педагога. Это благоприятствует согласованности транслируемого социокультурного опыта с жизненным опытом обучаемого, эмоциональному «включению» последнего в учебно-воспитательный процесс.
\end{abstract}

Ключевые слова: дискурс, педагогический дискурс, зона ближайшего развития, содержание образования, языкознание, педагогическая система, педагогический процесс, коммуникативная компетентность, компетентностный подход, науковедение, самоактуализация.

Научная специальность: 13.00.00 - педагогические науки. 